\title{
DESTINATION BRANDING: A CASE STUDY OF NATIONAL PARKS IN MONTENEGRO
}

\author{
Marija Janković, \\ Milena Bokić
}

\author{
${ }^{1}$ Mediterranean University, \\ Podgorica, Montenegro \\ ${ }^{2}$ Singidunum University \\ Belgrade, Serbia
}

Correspondence:

Marija Janković

e-mail:

marija.jankovic.mbs@gmail.com

\begin{abstract}
:
Destination branding is a complex and lengthy process that requires the definition of the concept of branding, planning and implementation, with interconnection and compliance of all steps, starting from market research, through development of identity and image, evaluation branding strategy to monitoring and auditing. Tourism in national parks is one of the fastest growing market segments of tourism demand in the global market. This paper deals with the improvement of development of national parks from the perspective of Montenegro as a destination brand. The natural heritage of each country's national parks occupies the special place. In Montenegro, national parks have the prospects and potential for developing different forms of tourism, recreation, excursions, sports and recreational tourism in the water (Black and Skadar Lake Biograd), to winter tourism (Lovćen, Durmitor, Bjelasica).
\end{abstract}

Keywords:

brand, tourism, national parks.

\section{INTRODUCTION}

Branding plays an important role in the process of carving a longterm niche for a tourism destination, directly affecting its development. Hence, in case of a national park, this role is of a special kind, due to the characteristics and peculiarities of the destination itself. It is of vital importance to invest in national and international tourism taking into account the fact that about 1.350 .000 people came in Montenegro in 2014 as tourists (WTO, 2016). In the modern world, tourism destinations tend to constantly develop more and more services for tourists. The way in which a particular destination gets to be represented in the minds of tourists stands out as the primary reason for choosing one particular destination over another and it can be directly used in the process of anticipating the steps that business rivals are about to take and establishing free space in the market available for a particular product of a destination (Popesku, 2008).

Tourism destination represents more or less rounded geographic entity that has attractive, communicative and receptive factors, i.e. all the natural, social, anthropogenic, cultural and historical, traffic and requirements for accommodation, food, vacation, recreation and amusement of tourists (i.e., built-tourism offer) (Bakić, 2005). The classified natural sights attract attention of a majority of modern tourists. In the tourism sector, the most important kind are probably national parks. Besides them, it is necessary to mention a number of existing natural reserves, 
natural parks, natural monuments, areas of wilderness, as well as the classified natural attractions of global significance-the biosphere reserves and the world heritage sites. The correlation between the classified natural sights and tourists has grown that strong that the concept of environmental protection in tourism has been introduced. Some states have established new classified natural sights, national parks, so as to preserve those off the beaten track from tourism overuse.

Creating a representation of a particular destination in one's mind is an intergral part of a successful destination marketing. The moment a particular representation of a destination is created, it has to, within the boundaries of its own marketing process, find its way to potential visitors. In case of natural parks, as a product in the form of a tourism destination, what should be stressed are the physical features of a destination, such as the natural environment that surrounds it: geographical peculiarities, places suitable for outdoor activities, particularities of flora and fauna etc. The positioning can also be carried out by listing the ways in which a person would benefit from visiting a particular place which, in case of national parks, is an escape from the urban daily routines, a great space for spending the weekend with a family or for vacation, magnificent sites for fishing, rafting, skiing, birdwatching, plant collecting, taking photos of rare animal and plant species. National parks of Montenegro represent natural treasure with its geological, biological and landscape diversity. Each park has its own individual beauty, which will be presented in this paper as a segment od differentiation, recognisability and authenticity.

The key element of positioning is selecting the market segments whose individual needs are still to be satisfied (Čerović, 2003). The purpose of this positioning strategy is to make a national park as a destination stand out compared to the rival destinations that can be the first substitute when it comes to changing a destination, which is a direct consequence of the overall market elasticity. The principles of sustainability have to be coordinated with a marketing strategy employed by the management of the national park.

\section{THE SPECIFICS AND CHARACTERISTICS OF NATIONAL PARKS IN MONTENEGRO}

The services offered by the national parks in Montenegro are diverse and appear in the form of:

- Visitor information centers

- Excursions, cruising and windsurfing

- Birdwatching and glacial lakes
- Rafting, kayaking and cycling-mountain bike

- Extreme sports and recreational fishing

- Ethno tourism, speleology and photo-safari

- Festivals and wine routes

- Restaurants and national cuisine.

The main aim of visitor information centers is raising the awareness and informing the visitors on the classified areas in Montenegro, presenting natural and cultural heritage in these areas, the traditional lifestyle of locals, as well as promoting the concepts of sustainable development and organizing field trips and other activities. There is a visitor information center in Vranjina, the national park Lake Skadar, and this center provides information on other national parks as well. It also boasts a rich collection of animal specimen, a room decorated in ethno style, the first room of that kind in that area, photos of endemic species, models of all national parks, an auditorium etc. Other centers contain collections of the species that characterize the given areas. Two more thematic visitor centers were open in the national park Lake Skadar in 2007, namely, the one in Murići, dedicated to olive cultivation and production, the handicraft and contribution of the Frontier, and the other one in Rijeka Crnojevića, dedicated to fishing and lake cruising.

The visitor information center of the national park Durmitor is located inside the headquarters of the national park. A collection of animal specimen of the national park that holds hundreds of taxidermied insects and animals that have the Durmitor belt and the river Tara canyon as their habitat, a souvenir shop, different brochures and tourist leaflets, an auditorium for about 30 visitors, can be found within the walls of the center. The center for visitors of the National park Prokletije is located at the crossroads between Alipaša's wells and Vusanje. It is an impressive building built and decorated in accordance with its natural surroundings, and a place where visitors can obtain all the information needed, both on the park itself and other services provided by the municipality Plav. The parks are also used for biology, history, geography and other field trips. With the educational programs, the centers become the meeting points for all those that invest their efforts in promoting and enhancing the importance of the parks. Visitor information centers have other contents which are constantly being updated. The centers have their souvenir shops, which are equipped with a variety of promotional materials (brochures, monographs, postcards, maps), and handmade items. That's the original way to represent part of ethno heritage.

Excursions represent the most popular tourist offer in the national park Lake Skadar, since it is the best way 
to get to know the landscape, natural heritage, historical, spiritual and cultural achievements of the people of Montenegro. Cruises are organized on a daily basis by locals in Virpazar, Vranjina and Plavnica. They include visits to the monasteries, churches, old fishing points and rural areas. Lake Skadar is also perfect for windsurfing and sailing. The winds that blow in this area throughout the year create excellent conditions for those that do that sport, both for the amateurs and those more experienced. Extreme conditions for sailing are quite rare on the lake. However, they can be very appealing to tourists and recreationists. The water in the lake is quite warm and suitable for sailing and enjoying the natural beauties of the lake. Bird watching is a popular pastime outdoor activity. Western Europe and America are the most popular sites for bird lovers, but the number of those in Montenegro country who decide to take up this interesting activity is growing on a daily basis.

Lake Skadar is an ideal habitat for birds, with 280 different avian types, which is $50 \%$ of the total number of species in Europe. The reason for such a great number of avian types, most of them being endemic and even endangered, lies in the biological, geographical and ecological peculiarities of the area, as well as in the good state of the ecosystem. The total fauna of the lake consists of 73 species that are nesting migratory birds, 18-regular visitors in autumn and spring, 45-winter guests, 12-regularly spend their summer without nesting and 90 species come to Lake Skadar at times.

A large number of birds on Lake Skadar and the existence of towers and platforms on Manastirska tapija, Grmožur, Omerova gorica, Crni žar and Pančevo oko create perfect conditions for bird watching. To try bird watching here can be a unique experience for all the bird lovers. The habitats of pelican, cormorant, heron, tern and other bird colonies are interesting to bird lovers. A small shallow boat or the towers and platforms can be used for bird watching.

A quite remarkable section of parks are the glacial lakes located in valleys and coves on the mountains. One can only get a complete grasp of all the lake's beauties and charms the moment one sets out to sail in its transparent and clear water. Shallow wooden boats can be used for this purpose. To get to explore a park in this particular way is a unique experience. There are 33 glacial lakes in Montenegro. The most famous are Black Lake on Mount Durmitor, Plav Lake at the foot of Mount Visitor and Biograd Lake on Bjelasica.

Hiking and climbing attract a number of tourists. Nature lovers can choose between many well-marked tracks. The tracks (the educational and the recreational ones) go through the woods and pass by the lake itself, the old settlements, monasteries and bridges. Following the tracks one can reach the top ( the viewpoints) and inspect the surroundings in the most peculiar and astonishing way. The most attractive viewpoints are those in the national park Lovćen from which one can view the landscapes of the inner parts of Montenegro, the Bay of Kotor and the Adriatic Sea. There are many resting points along the tracks. Hiking and climbing can be more or less demanding and may last for a couple of hours or even a couple of days. The coastal and mountaineering transversal route Orjen-Lovćen-Rumija is 138 $\mathrm{km}$ long and it connects two national parks-Lovćen and Lake Skadar to Rumija in the east and to Orjen mountain range in the west, along the coast of the Adriatic Sea.

The most appealing tourism brand of national parks is most certainly rafting on the most beautiful river, the longest $(93 \mathrm{~km})$ and the deepest $(1300 \mathrm{~m})$ canyon in Europe-the Tara River Canyon. Wooden rafts and rubber boats are available for those seeking adventure, whether they are amateurs or more experienced sportsmen. No matter how irksome the whirlpools and straits are, with the organizational help from national parks and other tourist bureaus and the skillful hands of the adventurers, they can be easily put under control. Tara's lakes and torrents in national parks render excellent conditions for kayaking, which is a real challenge for those in search of adventure, be they locals, or foreigners. In the summer season, these sportsmen and recreationists organize different competitions and outdoor activities in order to test their kayaking skills, but also to satiate their thirst for good wine and tasty fish dishes. Cycling, along with swimming, is the sport that most engages muscles. Mountain bike cycling is a sport of riding bicycles off-road, in the places such as woods, hills, mountains, roads, parks, meadows etc. Moreover, national parks provide perfect conditions for those who like being active during their vacation. There are many cycling tracks that lead through the woods, across paved roads and by the lake. Moreover, it is not only the cycling, but also the natural and cultural monuments that are to be seen along the way, which makes this activity an enjoyable one. One can also rent a bike. Moreover, a four-day stage race called "The paths of King Nikola" is organized each year in the national park Tara. There are many other festivals such as the following: The days of mountain flowers; the days of ecology, tourism and culture; the festival of wine and bleak etc. The abundance of national parks is reflected in the number of restaurants and other businesses operating there, something that only enhances the beauty of the area and the quality of one's time spent in national parks. 
CREATING A BRAND IDENTITY OF NATIONAL PARKS: THE EXAMPLE OF MONTENEGRO

Promotional activities, word-of-mouth and similar activities have the cruicial role in the process of drawing an identity in the mind of a potential costumer. By using the strategy of an identity profiling, tourism destination tends to create a position for themselves in the minds of customers of a previously established segment, this strategy being primarily the result of the nature and structure of their needs, as well as the characteristics of the product itself.

The image of the place and events associated with it exert a strong impact on tourists when choosing which destination they would like to visit. The image locates the position that a destination holds in the minds of tourists that plan a journey, heightening their expectations prior to the journey, as well as deepening the memories of a journey once it has finished. Strong brands do not only fulfill the rational needs, but they also trigger an emotional response (Solomon et al., 2006, p. 277). A brand generates loyalty, or the absence of it, depending on the emotions it arouses with a client.

As regards Montenegro, it is still quite difficult to discern whether the parks are branded, but we can try on the basis of above to represent the potentials of particular parks and the paths that the process of branding might take. As already stated, a brand is more than a mere product one should focus on that aspect of a particular site which is unique when compared to others. For example, Lake Skadar can be branded as a pelican breeding site, a bird that has been a trademark of this park for a long time. Another example would be the national park Lovćen that does not only commend itself for its beauties and plant diversites, but also for its cultural and historical importance. Therefore, the mausoleum of Petar II Petrović Njegoš should be taken as a brand of this park. Biogradska Gora has already established itself as a brand being the oldest rainforest in Europe, but further strengthening of this brand is needed. The national park Durmitor probably has the most diverse network of what to offer to tourists, but what stands out as a crown of its beauty and its importance is Black Lake. One should, in accordance with the management of these parks and their crucial peculiarities, try and enter the target group markets, and thus make them want to become part of the whole experience. Also, the marketing of national parks should be in close connection with management from these destinantions for reasons of its specificity in terms of ecology, where management is based on the principles of sustainable development.

\section{CONCLUSION}

We come to the conclusion that all marketing and promotional components of national parks as tourist products (should) work on the principles of sustainable development. This makes them specific in comparison with other segments of tourism as an economic sector, suitable for branding tourism destinations such as Montenegro. As national parks have based their strategy on sustainability, at the same time they contribute to the sustainable development through environmental protection and biodiversity on ecologically sensitive sites. With good marketing and promotional strategies, the value of the brand destinations in Montenegro can be increased.

Sustainable development, as well as the development of tourism in national parks, is very complex and must always be based on the protection of natural resources and their proper value and economic exploitation. That excludes all forms of mass tourism, which brings more problems than actual effects. On the other hand, with the maintenance of cultural and natural heritage of national parks of Montenegro, and the improvement of tourist offer, the increasing annual number of visitors and their better recognition in the world are achieved.

Sustainable tourism development in national parks is rather complex and its starting point should always be the protection of all natural resources and beauties, as well as the ways in which they are to be used more economically. As such, it excludes all forms of mass tourism that bring along problems rather than any real benefits. National parks in Montenegro offer diverse opportunities for development of particular forms of tourism, along with its natural abundance that is well-protected and clear, which is why their role is rather significant. Along with the development of sustainable tourism of national parks attains a higher income and protection, affirmation and popularization of these natural sights.

\section{REFERENCES}

Bakić, O. (2005). Marketing menadžment turističke destinacije. Beograd: Čigoja štampa.

Čerović, S. (2003). Menadžment u turizmu. Novi Sad: Prirodno-matematički fakultet.

Popesku, J. (2008). Menadžment turističke destinacije. Beograd: Univerzitet Singidunum.

Solomon, M.R., Marshall, G.W., \& Stuart, E.W. (2006). Marketing: Real people, real choices. Upper Saddle River, NJ: Pearson Prentice Hall. 
Vlada Crne Gore. (2002). Master plan: Strategija razvoja turizma Crne Gore 2020. Retrieved September 21, 2016 from http://www.gov.me/files/1054715117. PDF

World Tourism Organization. (2015). Yearbook of Tourism Statistics, Compendium of Tourism Statistics and data files. Retrieved September 07, 2016 from http://data.worldbank.org/indicator/ST.INT.ARVL 